\title{
Personality differences between academic team sport players and physical education undergraduate students
}

\author{
Aleksandra M. Rogowska ${ }^{\mathrm{ABCDE}}$ \\ University of Opole, Opole, Poland
}

Authors' Contribution: A - Study design; B - Data collection; C - Statistical analysis; D - Manuscript Preparation; E - Funds Collection.

\begin{abstract}
Purpose: $\quad$ Although personality research in psychology of sport has a long history, a little is known about the personality of the team sport players among university students. The aim of this study is to investigate differences in personality traits between Team Sport Players (TSP), Physical Education Students (PES) and Other Faculties Students (OFS).

Material: $\quad$ Participants in the cross-sectional study were 441 university students aged between 18 and 34 years old $(\mathrm{M}=22.09, \mathrm{SD}=2.19)$, including $60.09 \%$ of men, at a large university in the south of Poland. The NEO-FFI questionnaire was used to assess Big-Five personality traits.

Results: $\quad$ One-way ANOVA revealed that TSP sample scored significantly lower in neuroticism, openness and agreeableness than both PES and OFS groups. TSP also demonstrated higher scores in extraversion, in comparison to PES. The PES and OFS did not differ one another in personality traits. Conscientiousness was at the same level in all three groups.

Conclusions: Increasing achievement motivation and compliance with norms may heighten conscientiousness among undergraduates. The information about personality should be used by the coach to team conflict reduction, to make an appropriate selection decision and to develop individual development plans for particular team members.

Keywords: personality traits, big-five, undergraduates, physical education students, team sport players.
\end{abstract}

\section{Introduction}

Personality is understood as a theoretical construct, aimed at describing, explaining and predicting the way of human being and functioning in various aspects of life. Various personality concepts consider the individual differences in the cognitive and social context. Of the various psychological paradigms, theories based on the feature concept contributed significantly to the development of personality research. The five-factor personality model [1] includes scales describing the basic personality traits: neuroticism, extraversion, openness to experience, agreeableness and conscientiousness. These features are biologically determined and are subject of environmental influences. Personality traits of healthy individual contribute to shape the image of the self, attitudes, personal goals, self-confidence, and also it decides on the ways of adapting to changing environmental conditions [2-4]. Research [5] found, that a higher risk of mental disorders and heart disease may be related to the extreme intensity of a given personality dimension, as well as to the specific configuration of selected traits (e.g. high neuroticism and low openness).

The research on personality in sport psychology let us conclude, that athletic success and participation in physical activity can be good predicted by personality traits. Review study by Allen and Laborde [6] indicates that personality traits contributes to long-term athletic success, interpersonal relationships, and athletes' psychological states before, during, and after competitions.

\footnotetext{
(c) Aleksandra M. Rogowska, 2020

doi:10.15561/20755279.2020.0107
}

Personality traits are also related to health-related exercise over leisure-time, not only among young people but also in older ages. Moreover, personality can explain addictive exercise behaviors. In particular, high scores in neuroticism, extraversion, and conscientiousness, and also low levels of agreeableness are positively associated with exercise addiction [7-8].

In general, in comparison to non-athletes, athletes usually scored significantly higher in extraversion, and conscientiousness, and also they have lower levels of neuroticism [9-13]. Successful athletes score higher on conscientiousness on an objective measure of performance, and in conscientiousness and neuroticism in the coaches' ratings [14]. Conscientiousness and neuroticism were the best predictors of football ranks among 619,397 U.S. football players [15]. The level of competition has influence on the relationship between personality and sport performance. Athletes competing in national or international competitions report higher levels of conscientiousness and lower levels of neuroticism than do those competing in a club or regional competitions [16]. Longitudinal studies have also shown that athletes with a high level of conscientiousness and low neuroticism achieved statistically more sports successes over the course of a competitive season [14]. Meta-analytic review [17] revealed that performance motivation was the strongest and positively correlated with conscientiousness and negatively with neuroticism, due to such theoretical perspectives, as goal-setting, expectancy, and self-efficacy motivation. Recent research [18] found that mental toughness is strongly related to the 
extraversion, emotional stability (reverse of neuroticism) and conscientiousness scales of the HEXACO model of personality. These traits are related to ambition as a facet of competitive, self-confident, accomplishment, and leadership, which may explain the better sport performance of people with higher mental toughness.

The personality of players representing team and individual sports was also compared, although the results of these studies are ambiguous. Some research indicates that there are differences between team and individual sport participants, that is mainly related to the levels of social interaction. Among five traits of personality, in particular higher levels of extraversion seem related to more successful group performances [19]. Behzadi et al. [20] found that team athletes have higher levels of extraversion and scored lower in neuroticism than individual athletes. However, Nia and Besharat [21] demonstrated that team sport players have higher agreeableness in comparison to individual athletes, but no significant difference between the two groups on neuroticism, extraversion, and openness was found. The other study [22] indicates that team athletes demonstrate lower levels of extraversion, openness and conscientiousness, in comparison to individual sportsmen. It is important to note, that team member personality is associated with various aspects of team functioning and effectiveness, beside personality traits, such as task-oriented behavior, team processes, team roles (leadership in particular), contextual performance, team influence of the individual, the individual influence of the team, collective personality as a team trait, trait interaction, and team staffing [23].

Football, handball, volleyball, and basketball players experience a large number of injuries [2425]. Understanding injury risk factors is necessary to identify the injury-prone athletes and to develop appropriate injury prevention plans. Beside physical and biomechanical injury risk factors, psychological factors are currently widely considered as an important risk factor predictor [26-28]. It was found, that cognitive and somatic anxiety may increase the injury occurrence due to poor concentration and physiological changes in football players [24]. Personality may also indirectly be related to higher risk of injury in athletes.

Moreover, personality may be also useful toll to predict rehabilitation success after sport injury. A prospective, longitudinal study revealed that Big-Five personality characteristics may predict adherence to clinic-based rehabilitation activities following anterior cruciate ligament (ACL) reconstruction surgery [29]. Agreeableness was found as a significant positive predictor of attendance, while conscientiousness and openness to experience were significant positive predictors of adherence ratings.

Personality contributes also to physical-activity levels among people not related to elite sport participation [6]. It was generally found, that high level of extraversion and conscientiousness and low levels of neuroticism relate to higher levels of physical activity. On the other hand, low levels of conscientiousness, extraversion, and openness and high levels of neuroticism determines a greater occurrence of leisure-time sitting time [6]. A gender differences in relation between physical activity and personality traits were also found [30]. Openness to experience was a significant predictor of moderate physical activity in females, whereas agreeableness, emotional stability and conscientiousness were related to vigorous physical activity in males.

There are also a few studies examined the personality traits among Physical Education students. Francis et al [31], compared the personality traits of female students who play hockey (as a member of university hockey clubs) with a control group of female students with no formal involvement in sport. The hockey players emerged as significantly higher in extraversion and psychoticism (high psychoticism of Eysenck's EPQ may be seen as an equivalent of low agreeableness). McKelvie et al. [32] found that undergraduate athletes scored significantly lower in neuroticism than non-athletes, but extraversion did not distinguish these groups. The study of Talyabee's et al. [33] indicates that the sample of Iranian university students differs significantly from athlete students in personality traits. Athletes scored higher in extraversion, agreeableness and conscientiousness, and they scored lower in neuroticism, when compared to non-athletes. The sample of Polish PE students [34] scored low in neuroticism and high in extraversion, agreeableness and conscientiousness, and they show an average level of openness. In addition, positive relationship between openness and sports interests was found. More recent study [35] indicates that PE students $(n=213)$ presented significantly lower scores in the neuroticism scale, as well as they scored significantly higher in extraversion, agreeableness and conscientiousness, when compared to students of other faculties $(n=241)$.

\section{Purpose}

There are many reasons to continue research on personality among people at distinct levels of physical activity. Allen and Laborde [6] state that the role of personality in sport teams and exercise groups has received little empirical attention. In the present study we will explore the differences between team sports athletes and physical education students, in comparison to students of other academic faculties, who most likely presents a lower level of exercise and health-related physical activity. Explaining differences in personality can be helpful in preparing the best strategies for preventing sedentary lifestyle among young adults, and also in developing effective training plans by couches, to increase success among university team athletes.

\section{Hypothesis}

The main hypothesis is, that Team Sport Players (TSP) differ in personality traits in comparison to Physical Education (PES) Students and also in comparison to Other Faculties Students (OFS). Because the results of previous studies are ambiguous [19-22], we cannot predict the particular outcomes. The differences between OFS and both PES and TSP should mainly base on the level of physical activity [9-13], as well as previous research on 
differences between athletes and non-athletes university students [31-35]. Thus, both TSP and PES groups should demonstrate higher extraversion and conscientiousness, and lower neuroticism, than the OFS sample. Also, agreeableness may be higher in PE students, when compared to the other faculties [33-35].

\section{Material and Methods}

\section{Participants}

Participants in the study were 441 university students (including $60.09 \%$ of men, $n=265$; and $39.91 \%$ of women, $n=176)$, aged between 18 and 34 years old ( $M$ $=22.09, S D=2.19$ ). Undergraduates have studied at a large university in the south of Poland. Most of them were Physical Education Students (PES, $62.87 \%$ of the total sample), including Team Sport Players (TSP, 25\% of the total sample). The TSP participants are members of the Academic Sport Association, in the following sections: Basketball $(n=51)$, Football $(n=41)$, and Volleyball $(n$ $=20$ ). The TSP individuals took everyday sport training and they frequently participated in competitions on the academic level. The sample of Other Faculties Students (OFS, $36.73 \%$ of the total sample) represents the following fields: Physiotherapy, Tourism and Recreation, Management and History. The number and percentage of student distribution in particular fields by studying show Table 1.

\section{Procedure}

The cross-sectional study was conducted at a large university in the south of Poland. The students anonymously and voluntarily completed the NEO-FFI questionnaire during the didactic classes at the university, with the consent of lecturers. The NEO Five-Factor Inventory (NEO-FFI) was used to measure personality traits by standard 'paper and pencil' questionnaires [1]. The NEO-FFI comprises 60 items, 12 belonging to each of the following five subscales: Neuroticism, Extroversion, Openness to experience, Agreeableness, and Conscientiousness. All items are answered on a 5-point Likert scale, ranging from $0=$ strongly disagree, to $4=$ strongly agree. The reliabilities indicated an acceptable internal consistency (Cronbach's alpha) in the Polish version of the NEO-FFI [5], for the following scales: Neuroticism $(\alpha=.80)$, Extraversion $(\alpha=.77)$, Openness ( $\alpha$ $=.68)$, Agreeableness $(\alpha=.68)$ and Conscientiousness $(\alpha=$ .82). The Cronbach's alpha for the scales of Neuroticism, Extroversion, Openness to experience, Agreeableness and Conscientiousness, in the present study were $.83, .70, .60$, .71 , and .71, respectively.

\section{Statistical Analysis}

The following statistical analysis were performed: analysis of the reliability of the NEO-FFI scales by using Cronbach's $\alpha$ coefficient, and analysis of intergroup differences (between TSP, PES, and OFS samples) for particular personality traits (Neuroticism, Extraversion, Openness to experience, Agreeableness and Conscientiousness), by using the One-way ANOVA, with the Fisher's Least Significant Difference (LSD) post-hoc test. All statistical analysis was conducted by using the STATISTICA 13.1 software.

\section{Results}

The one-way ANOVA was conducted to examine differences between three groups of undergraduates

Table 1. Characteristic of the sample $(N=441)$

\begin{tabular}{lll}
\hline Groups of Undergraduates & $n$ & \% \\
\hline Team Sport Players & 112 & 25.00 \\
Football & 41 & 9.30 \\
Volleyball & 20 & 4.54 \\
Basketball & 51 & 11.56 \\
\hline Physical Education Students & 167 & $\mathbf{3 7 . 8 7}$ \\
\hline Other Faculties Students & 162 & 36.73 \\
Physiotherapy & 25 & 5.67 \\
Tourism and Recreation & 65 & 14.74 \\
Management & 42 & 9.52 \\
History & 30 & 6.80 \\
\hline
\end{tabular}

Table 2. Results of one-way ANOVA for the particular personality traits

\begin{tabular}{lllllllll}
\hline \multirow{2}{*}{ Personality traits } & \multicolumn{2}{l}{ Team Sport Players } & \multicolumn{2}{l}{ PE Students } & \multicolumn{2}{l}{$\begin{array}{l}\text { Other Faculties } \\
\text { Students }\end{array}$} \\
\cline { 2 - 11 } & $M$ & $S D$ & $M$ & $S D$ & $M$ & $S D$ & $F(2,438)$ & $p$ \\
\hline Neuroticism & 16.71 & 6.97 & 18.87 & 7.06 & 20.38 & 8.80 & 7.48 & .001 \\
Extraversion & 32.22 & 4.98 & 30.39 & 5.50 & 31.47 & 5.80 & 3.94 & .020 \\
Openness & 25.19 & 5.68 & 26.96 & 5.25 & 27.17 & 5.30 & 5.14 & .006 \\
Agreeableness & 27.91 & 5.66 & 29.99 & 5.53 & 29.61 & 5.76 & 4.89 & .008 \\
Conscientiousness & 32.70 & 6.24 & 31.98 & 5.96 & 32.15 & 6.65 & 0.45 & .639 \\
\hline
\end{tabular}


(TSP, PES, and OFS) in the particular personality traits. As it is shown in Table 2, significant differences were found for neuroticism, extraversion, openness and agreeableness. The three groups assessed relatively high level of conscientiousness, without significant differences between the TSP, PES, and OFS samples.

The Fisher's LSD post-hoc test was conducted to identify which pairs of means are statistically different. The results are presented in Figure 1. The significant differences between TSP and PES samples were found in neuroticism, extraversion, openness and agreeableness dimensions of personality. The TSP group scored lower than the PES group in neuroticism, openness and agreeableness, and they also scored significantly higher in extraversion. The significant differences between TSP and OFS samples regards such personality traits, as neuroticism, openness and agreeableness. The TSP sample scored lower than OFS group in all of these scales. No differences between PES and OFS were found in personality traits.

\section{Discussion}

The present study has examined how personality traits are determined by the level of physical activity of university students. Due to previous research [19-22], it was supposed, that the TSP group differs from both PES and OFS samples in personality traits. In addition, both TSP and PES groups should score higher in extraversion and conscientiousness and lower in neuroticism than the
OFS sample [9-13, 31-35]. The present research partially confirmed these hypotheses.

Consistent with expectations, neuroticism was significantly lower and extraversion was significantly higher in the TSP sample than in both PES and OFS groups. The pattern of low neuroticism and high extraversion in athletes seems to agree with most of previous studies [9-13, 31-35]. Low level of neuroticism demonstrates tendency to be emotionally stable, optimistic, and to effectively cope with stress. Extraversion expresses the tendency to be sociable, assertive, to have a high level of energy, to seek excitement and adventures and to frequently experience positive affect. Athletes with high levels of extraversion or low levels of neuroticism better cope with unsuccessful outcomes [6]. There is evidence, that these traits characterize stabile personality and can predict success and good quality of life [1-4].

The study indicates that team athletes possess specific configuration of personality traits, such as lower level of neuroticism, openness and agreeableness, in comparison to the other undergraduates. In addition, the TSP sample differs significantly from the PES group in terms of higher extraversion. Low neuroticism and openness, as well as high extraversion and conscientiousness were founded by an elite team of wrestlers [36]. Higher extraversion among team players, as compared to individual athletes, was also found in the previous studies [19-20]. Heightened extraversion favors social interaction and may be helpful to develop social skills, what is very valuable

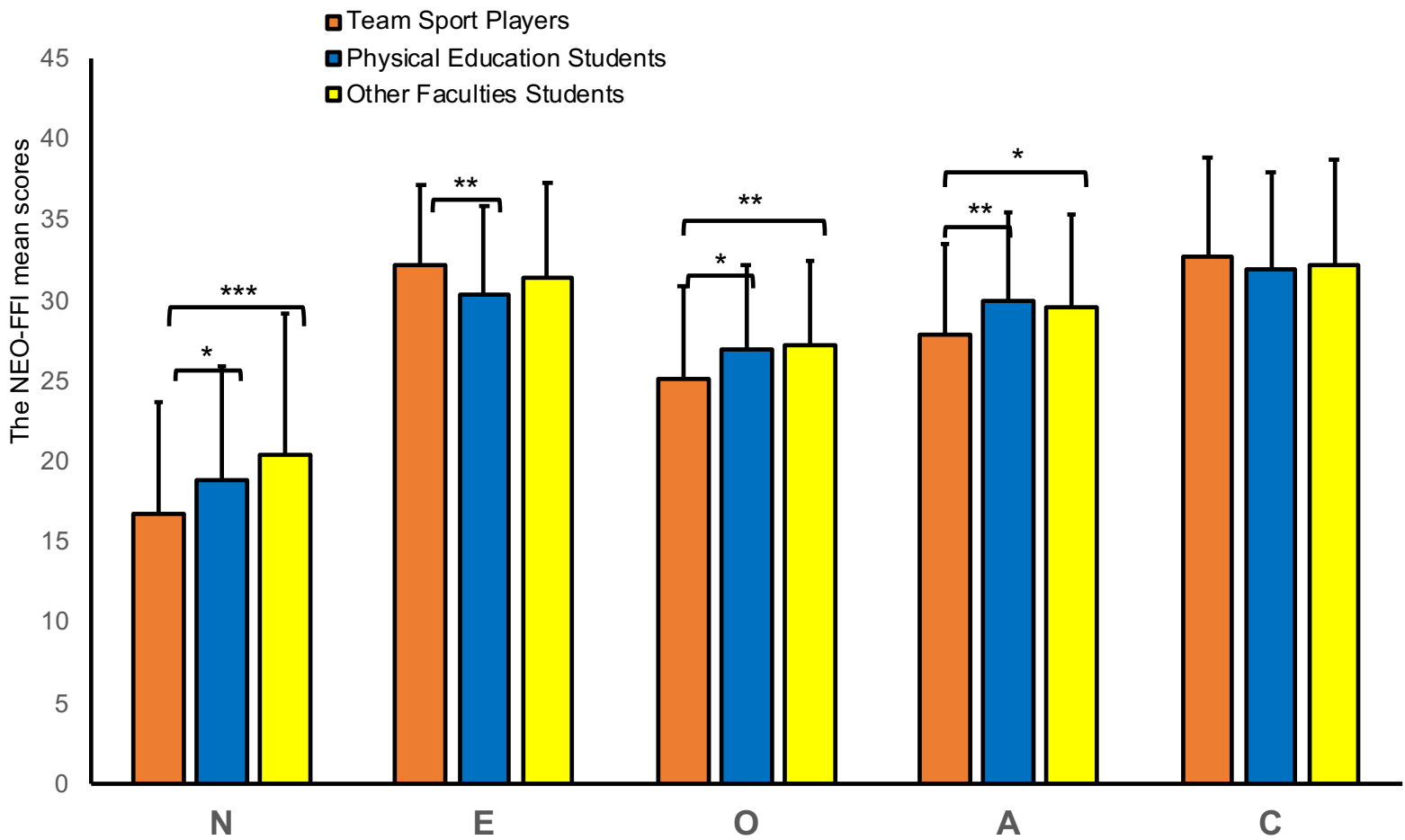

Figure 1. The NEO-FFI mean scores of the three groups of undergraduates: Team Players, Physical Education students and Other Faculties Students, in particular traits of personality. $\mathrm{N}=$ Neuroticism, $\mathrm{E}=$ Extraversion, $\mathrm{O}=\mathrm{Openness}, \mathrm{A}=$ Agreeableness, $\mathrm{C}=$ Conscientiousness. The Error bars are standard deviation. Significant differences between groups are highlighted by $* p<.05, * * p<.01, * * * p<.001$. 
in a team sport. Allen and Laborde [6] mentioned, that people participating in group exercise classes present higher adherence levels when the group leader or the group members has higher scores on extraversion. Thus, extraversion is an important trait for athletes as a member of the team as well as to be a coach.

High openness to experience is a tendency to be perceptive, reflective, creative, with wide fantasy, to be curious about the world and people, and to appreciate the aesthetics. This characteristic may be not very useful in sport participation. However, agreeableness seems to be a very valuable trait in team working. Agreeableness is the tendency to be kind, trustworthy, cooperative (instead of competitive), altruistic, and generous. It has also been found that sport participants with high levels of agreeableness or conscientiousness report more favorable relationships with their teammates and coaches [6]. Laios and Alexopoulos [37] examined the main causes of conflict between coaches and players in professional basketball teams in Greece. Among six main causes of conflict between coaches and players, the "personality clashes" was considered by the professional basketball coaches as the main cause which can engage in conflict. High agreeableness may be the trait mainly related to limited conflicts, excellent cooperation and good interrelationship in the team. On the other hand, people who strive for success in competition, should rather pose low agreeableness.

Hogan and Sherman [38] presented the theory of human nature, which assumes that personality determines and explains both forms of competition: in groups for individual status and between groups for collective survival. Success in group competition depends on social skills, and success between groups depends on leadership. Team players, depend on the team role, may need higher or lower levels of extraversion and agreeableness. Kim et al. [39] demonstrated that athlete personality may underpin the processes by which athletes come to occupy informal roles on their teams. For example, the team mentors tended to be more emotionally stable, team star players seem to be less agreeable.

The present study is not consistent with some previous research on differences between team and individual athletes [21-22]. The discrepancy between personality traits that characterize team sport athletes may be determined by the fluctuations of the group dynamic processes. Ramos-Villagrasaa et al. [40] analyzes the dynamic of basketball player's effectiveness, in relation to personality, job experience, and motivation. They found that the relevance of the predictors of effectiveness was different each time they are analyzed throughout a sport season. In addition, all variables except conscientiousness predict the fluctuations of effective performance, and openness to experience was the most influential predictor.

Conscientiousness did not differentiated undergraduates in this study at all. Highly conscientious individuals are characterised as being reliable, hardworking, ordered, dutiful, self-disciplined and achievement oriented [1]. A relationship has also been demonstrated between conscientiousness as a personality trait and life expectancy. Conscientious people are less likely to take risks leading to an unfortunate accident, they were also less likely to be addicted to tobacco and alcohol than those who were not conscientious, but more often they followed the principles of a healthy life - they ate healthy, regularly did physical exercises, underwent periodic medical examinations and took medication prescribed for them. In sport area, conscientiousness may reflect the degree to which athletes train in systematic and focused tasks way, and to how extend they follow the rules and regulations. Conscientiousness has showed positive significant correlation with success in sport performance in many previous studies [6, 14-16]. Athletes higher in conscientiousness use usually better preparation strategies, take fewer reckless risks, and use more effective coping strategies $[6,41]$. There is evidence that conscientiousness-related traits are negatively associated with risky health-related behaviours [42-43].

Interesting, mean scores in all personality traits were similar in both the PES and OFS groups, which is inconsistent with previous studies [33-35]. However, it is important to note, that the group of PE students could comprise athletes associated in academic sport clubs, such as the Academic Sport Association. Thus, the differences found in previous studies [33-35] may be a mixed group effect. Future studies should take into account discrete difference between PE student athletes and those PE students, who are recreational rather involved in physical activity. The other possible explanation of the discrepancy between the current and previous study is, that although Physical Education students participate in many classes that needed engagement in physical exercise, they seem do not reveal personality traits characterizing physically active people. On the other hand, it may be that the sample of OFS demonstrates personality traits, which are associated with the heightened physical activity. Unfortunately, the physical activity was not carefully controlled in this study, so this issue cannot be resolved. Further study should examine engagement in physical activity more accurate.

Personality is useful to explain exercise behavior. The study [44] revealed that facet-level personality traits of activity and self-discipline are important motivational variables to explain exercise behavior, based on the Theory of Planned Behavior (TPB). In particular, the extraversion and conscientiousness facet-level traits of activity and self-discipline were found as a predictor of exercise behavior. In addition, the intention-behavior relationship was moderated by the anxiety facet trait of neuroticism. Ingledew et al. [45] examined the mechanism underlying association between personality and exercise behavior, using self-determination theory. The study found that neuroticism was associated with introjected regulation, extraversion with identified and intrinsic regulation, openness with less external regulation, and conscientiousness with intrinsic regulation. Researchers concluded that extroverted individuals are able to feel self-determined because exercise can satisfy the need for 
relatedness, whereas conscientious individuals because exercise can satisfy the need for competence.

In team sports, personality diagnosis can be used to select players to a particular team or competition [46]. Research [47] indicates, that coach's diagnosis of personality traits of hockey players is very helpful in an accurate and valid prediction about an athlete's long term success in professional sport, in particular when performance is assessed longitudinally within a relatively homogenous sample of athletes. Therefore, it is recommended for coaches to routinely employ a battery of tests before selection decision. According to Allen and Laborde [6], it is necessary to increase the role of consultant personality traits in applied research and professional practice.

\section{Conclusions}

It seems, that differences between TSP and other students (both PES and OFS), found in the present study, are consistent with differences between athletes and nonathletes, demonstrated in previous research [9-13]. Low neuroticism in configuration with high extraversion seems to be the best distinguishing personality traits for athletes. Team players in this study may be described by configuration of low levels of neuroticism, openness and agreeableness. Low agreeableness may be helpful in successful achievement, because of competitive attitude. On the other hand, however, low agreeableness may limit cooperation in team. Juxtaposition low agreeableness with low openness may promote conflicts in the team. The Coach should develop appropriate strategies to

\section{References}

1. Costa P, McCrae R. The Revised NEO Personality Inventory. Odessa, FL: Psychological Assessment Resources; 1992.

2. Campbell JB, Hall CS, Gardner L. Teorie osobowości [Theory of personality]. Warsaw: PWN; 2006 (in Polish)

3. Pervin LA, John OP. Osobowość. Teoria $i$ badania [Personality. Theory and research]. Kraków: Publishing house UJ; 2002 (in Polish).

4. Strelau J. Osobowość jako zespót cech [Personality as a set of traits]. In: Strelau J, editor. Psychologia. Podręcznik akademicki [Psychology. Academic handbook]. Vol. 2. Gdańsk: GWP; 2000. P. 525-560 (in Polish)

5. Zawadzki B, Strelau J, Szczepaniak P, Śliwińska M. Inwentarz osobowości Costy i McCrae: Adaptacja polska [Personality inventory NEO-FFI by Costa and McCrae: Polish adaptation]. Warsaw: PTP; 1998.

6. Allen MS, Laborde S. The Role of Personality in Sport and Physical Activity. Curr Dir Psychol Sci. 2014;23(6):460-465. https://doi.org/10.1177/0963721414550705

7. Andreassen CS, Griffiths MD, Gjertsen SR, Krossbakken E, Kvam S, Pallesen S. The relationships between behavioral addictions and the five-factor model of personality. $J$ Behav Addict. 2013;2:90- 99. https://doi.org/10.1556/JBA.2.2013.003

8. Hausenblas HA, Giacobbi PRJr. Relationship between exercise dependence symptoms and personality. Pers Individ Differ. 2004;36:1265- 1273. https://doi.org/10.1016/S0191-8869(03)00214-9 cope with team conflicts, as well as to promote tolerant attitude towards teammates. In the present study, conscientiousness was almost identical in all three groups compared. Lower conscientiousness may determine low academic achievements in PES and OFS, and also low effectiveness in sport. The trainer should develop more regularity, routine, discipline and diligence in athletes by increasing achievement motivation and internal motivation. In addition, team norms should be clearly defined and enforced for all team members. In in cooperation with a sport psychologist, coach should use the information about athletes' personality to make selection decision and to develop individual development plans for particular team members.

\section{Highlights}

- Undergraduate students playing team sports differ from physical education and other faculty's students in term of lower in neuroticism, openness and agreeableness.

- Team sport athletes scored higher in extraversion than Physical Education non-athlete students.

- Personality traits in a non-athlete undergraduate students are similar, independent on physical activity level and faculty of the study.

- Conscientiousness was at the same level in all three groups.

- Personality knowledge should be a useful tool in coaching.

\section{Conflict of interest}

There are no conflicts of interest.

9. Bernatek P, Cywil S, Dudziak D, Szastarek I, Guszkowska M. Cechy temperamentu i osobowości zawodników sportów walki i zespołowych gier sportowych [Temperament and personality traits of martial arts and team sports players]. In: Parzelski D, editor. Psychologia $w$ sporcie. Teorie. Badania. Praktyka [[Psychology in sport. Theory, Research. Practice]. Warsaw: UW; 2006. P. 50-57 (in Polish) . https://doi.org/10.31338/uw.9788323526636.pp.50-57

10.Borysiuk Z. Psychomotoryczne $i$ osobowościowe uwarunkowania poziomu mistrzowskiego $w$ szermierce [Psychomotor and personality conditioning of the master level in fencing]. Opole: PO; 2002 (in Polish)

11. Rhodes RE, Smith NE. Personality correlates of physical activity: A review and metaanalysis. $B r \quad J$ Sport Med. 2006;40:958-965. https://doi.org/10.1136/bjsm.2006.028860

12.Rychta T. Osobowość $i$ celowe zachowanie sportowców [Personality and goal-behavior of athletes]. Warsaw: COS; 1998 (in Polish)

13.Stawowska L. Psychologiczna diagnoza $w$ sporcie wyczynowym [Psychological diagnosis in competitive sport]. Katowice: AWF; 1989 (in Polish)

14.Piedmont RL, Hill DC, Blanco S. Predicting athletic performance using the five-factor model of personality. Pers Individ Differ. 1999;27:769- 777. https://doi.org/10.1016/S0191-8869(98)00280-3

15.TranX.FootballScoresontheBigFivePersonalityFactorsacross 50 States in the U.S. J Sports Med Doping Stud. 2012;2:117. 
https://doi.org/10.4172/2161-0673.1000117

16.Allen MS, Greenlees I, Jones MV. An investigation of the five-factor model of personality and coping behaviour in sport. $J$ Sports Sci. 2011;29:841- 850. https://doi.org/10.1080/02640414.2011.565064

17.Judge TA, Ilies R. Relationship of personality to performance motivation: A meta-analytic review. J App Psychol. 2002;87(4):797- 807. https://doi.org/10.1037/0021-9010.87.4.797

18. Yankov GP, Davenport N, Sherman RA. Locating mental toughness in factor models of personality. Personality and Individual Differences, 2019;151:109532. https://doi.org/10.1016/j.paid.2019.109532

19.Jarvis M. Sport Psychology: A student's handbook. NY: $\quad$ Routledge; 2006. https://doi.org/10.4324/9780203965214

20.Behzadi F, Mohammadpour A, Hedayatikatooli A, Nourollahi H. A description and comparison of personality traits of competitive individual and team athletes. Ann Bioll Res. 2012;3(1):36-40.

21.Nia ME, Besharat MA. Comparison of athletes' personality characteristics in individual and team sports. Procedia Soc Behav Sci. 2010;5:808-812. https://doi.org/10.1016/j.sbspro.2010.07.189

22.Ilyasi G, Salehian MH. Comparison of personality traits between individual and team athletes. Middle-East J Sci Res. 2011;9(4):527-530.

23.LePine JA, Buckman BR, Crawford ER, Methot JR. A review of research on personality in teams: Accounting for pathways spanning levels of theory and analysis. HRMR. 2011;21:311-330. https://doi.org/10.1016/j.hrmr.2010.10.004

24.Alizadeh MH, Pashabadi A, Hosseini SM, Shahbazi M. Injury occurrence and psychological risk factors in junior football players. WJSS. 2012;6(4):401-405.

25.Barber Foss KD, Myer GD, Hewett TE. Epidemiology of basketball, soccer, and volleyball injuries in middle-school female athletes. Phys Sportsmed. 2014;42(2):146-153. https://doi.org/10.3810/psm.2014.05.2066

26.Deroche T, Stephan Y, Woodman T, Le Scanff C. Psychological Mediators of the Sport Injury-Perceived Risk Relationship. Risk Analysis. 2012;32(1):113-121. https://doi.org/10.1111/j.1539-6924.2011.01646.x

27.Devantier C. Psychological predictors of injury among professional soccer players. Sport Sci Rev. 2011;20(5-6):5-36. https://doi.org/10.2478/v10237-011-0062-3

28.Slimani M, Bragazzi NL, Znazen H, Paravlic A, Azaiez F, Tod D. Psychosocial predictors and psychological prevention of soccer injuries: A systematic review and meta-analysis of the literature. Phys Ther Sport. 2018;32:293-300. https://doi.org/10.1016/j.ptsp.2018.05.006

29.Hilliard RC, Brewer BW, Cornelius AE, Van Raalte JL. Big Five Personality Characteristics and Adherence to clinic-based rehabilitation activities after ACL surgery: A prospective analysis. Open Rehabil J. 2014;7:1-5. https://doi.org/10.2174/1874943701407010001

30.Aşçi FH, Altintaş A, Edepli Gürsel N, Lindwall M. Gender differences in the relation of personality traits and self-presentation with physical activity. Sci Sports. 2015;30(1):e30, e23-e30. https://doi.org/10.1016/j.scispo.2014.07.016

31.Francis LJ, Kelly P, Jones SJ. The personality profile of female students who play hockey. Irish J Psychol. 1998;19:394-399. https://doi.org/10.1080/03033910.1998.10558199

32.McKelvie S, Lemieux P, Stout D. Extraversion and neuroticism in contact athletes, no contact athletes and nonathletes: A research note. Athletic Insight. 2003;5(3):19-27.

33. Talyabee SR, Moghadam RS, Salimi M. The investigation of personality characteristics in athlete and non-athlete students. Euro J Exp Biol. 2013;3(3):254-25.

34.Rogowska A. Osobowościowe wyznaczniki zainteresowań sportowych [Personality determinants of sport interests]. In: Wojnar J, Wojciechowska-Maszkowska B, Tataruch R, editors. Wykorzystywanie badań naukowych $w$ wychowaniu fizycznym i sporcie. Praca badawcza z 4 obszarów aktywności ruchowej: sport, wychowanie fizyczne, rekreacja ifizjoterapia [The use of scientific research in physical education and sport. Research work in 4 areas of physical activity: sport, physical education, recreation and physiotherapy]. Opole: Holy Cross Publishing House and Printing House; 2009. P. 47-57 (in Polish)

35.Rogowska A, Wojciechowska-Maszkowska B, Borzucka D. Osobowość studentów wychowania fizycznego w kontekście roli trenera i wychowawcy [Personality of physical education students in the context of the role of a trainer and educator]. In: Kostorz J, Rogowska A, editors. Osobowość trenera - wychowawcy $w$ kulturze fizycznej. Olimpiada wiedzy $i$ wartości $w$ sporcie [Personality of the trainer - educators in physical culture. Olympics of knowledge and values in sport]. Opole: Studio IMPRESO; 2015. P. 47-61 (in Polish)

36.Tomczak M, Bręczewski G, Sokołowski M, Kaiser A, Czernik U. Personality traits and stress coping styles in the Polish National Cadet Wrestling Team. Arch Budo. 2013;9(3):161-68.

37.Laios A, Alexopoulos P. The sources of conflict in professional basketball teams. The case of Greece. Proc Soc Behav Sci. 2014;152:343- 347. https://doi.org/10.1016/j.sbspro.2014.09.207

38.Hogan R, Sherman RA. Personality theory and the nature of human nature. Pers Individ Differ. 2020;152:109561. https://doi.org/10.1016/j.paid.2019.109561

39.Kim J, Gardant D, Bosselut G, Eys M. Athlete personality characteristics and informal role occupancy in interdependent sport teams. Psychol Sport Exerc. 2018;39:193- 203. https://doi.org/10.1016/j.psychsport.2018.07.011

40.Ramos-Villagrasaa PJ, Garcia-Izquierdoa AL, Navarrob J. Predicting the dynamic criteria of basketball players: The influence of the 'Big Five', job experience, and motivation. EJWOP. 2013;29:29- 35. https://doi.org/10.5093/tr2013a5

41.Mirzaei A, Nikbakhsh R, Sharififar F. The relationship between personality traits and sport performance. Euro $J$ Exper Biol. 2013;3(3):439-442.

42.Bogg T, Roberts BW. Conscientiousness and health-related behaviors: a meta-analysis of the leading behavioral contributors to mortality. Psychol Bull. 2004;130(6):887-919. https://doi.org/10.1037/0033-2909.130.6.887

43.Merritt CJ, Tharp IJ. Personality, self-efficacy and risk-taking in parkour (free-running). Psychol Sport Exerc. 2013;14(5):608- 11. https://doi.org/10.1016/j.psychsport.2013.03.001

44.Hoyt AL, Rhodes RE, Hausenblas HA, Giacobbi PRJr. Integrating five-factor model facet-level traits with the theory of planned behavior and exercise. Psychol Sport Exerc. 2009;10:565- 572. https://doi.org/10.1016/j.psychsport.2009.02.008

45.Ingledew DK, Markland D., Sheppard KE. Personality and self-determination of exercise behaviour. Pers Individ Differ. 2004;36:1921- 1932. https://doi.org/10.1016/j.paid.2003.08.021 
46.van Rossum JHA. Giftedness and talent in sport. In: Shavinina LV, editor. International Handbook on Giftedness. Dordrecht: Springer; 2009. P. 751- 791. https://doi.org/10.1007/978-1-4020-6162-2_37
47.Gee CJ, Marshall JC, King JF. Should coaches use personality assessments in the talent identification process? A 15 year predictive study on professional hockey players. Int $J$ Coa Sci. 2010;4(1):25-34.

\section{Information about the author:}

Aleksandra M. Rogowska; http://orcid.org/0000-0002-4621-8916; arogowska@uni.opole.pl; Institute of Psychology, University of Opole; Opole, Poland.

\section{Cite this article as:}

Aleksandra M. Rogowska. Personality differences between academic team sport players and physical education undergraduate students. Physical education of students, 2020;24(1):55-62.

https://doi.org/10.15561/20755279.2020.0107

This is an Open Access article distributed under the terms of the Creative Commons Attribution License, which permits unrestricted use, distribution, and reproduction in any medium, provided the original work is properly cited http://creativecommons.org/licenses/by/4.0/deed.en

Received: 26.10 .2019

Accepted: 23.11.2019; Published: 04.02.2020 